\title{
Influence of Farming System on Weed Infestation and on Productivity of Narrow-Leaved Lupin (Lupinus angustifolius L.)
}

\author{
Agnieszka Faligowska ${ }^{1, *}$, Katarzyna Panasiewicz ${ }^{1}$, Grażyna Szymańska ${ }^{1} \oplus$, \\ Karolina Ratajczak ${ }^{1}{ }^{(\mathbb{D}}$, Hanna Sulewska $^{1}{ }^{1}$, Agnieszka Pszczółkowska ${ }^{2}$ and Anna Kocira ${ }^{3}{ }^{\mathbb{C}}$ \\ 1 Department of Agronomy, Faculty of Agronomy and Bioengineering, Poznań University of Life Sciences, \\ Dojazd 11, 60-632 Poznań, Poland; katarzyna.panasiewicz@up.poznan.pl (K.P.); \\ grazyna.szymanska@up.poznan.pl (G.S.); karolina.ratajczak@up.poznan.pl (K.R.); \\ hanna.sulewska@up.poznan.pl (H.S.) \\ 2 Department of Phytopathology, Entomology and Molecular Diagnostics, University of Warmia and Mazury, \\ 10-719 Olsztyn, Poland; agnieszka.pszczolkowska@uwm.edu.pl \\ 3 Institute of Agricultural Sciences, State School of Higher Education in Chełm, Pocztowa 54, \\ 22-100 Chełm, Poland; akocira@pwsz.chelm.pl \\ * Correspondence: agnieszka.faligowska@up.poznan.pl
}

Received: 3 September 2020; Accepted: 5 October 2020; Published: 8 October 2020

\begin{abstract}
Legumes have become important crops, due to an increasing global population and its demand for feed protein. Furthermore, legumes can improve the characteristics of the soil, improve biodiversity levels in crop rotations, and be cultivated in both organic and sustainable farming systems. In this study, a two-factor field experiment was conducted in Gorzyń, Poland in 2011-2015. The first factor was the farming system: low-external inputs (LI; without fertilization and chemical protection), medium-input (MI; medium fertilization level and chemical protection), and high-input (conventional-CONV; high fertilization level and chemical protection). Narrow-leaved lupin cultivar was the second factor; the indeterminate cv. Kalif and the determinate cv. Regent. We evaluated (a) weed infestation levels, (b) seed and protein production, and (c) the economic effects of narrow-leaved lupin cultivation under different farming conditions. A total of 12 weed species were identified, with the lowest weed density level and biomass production observed in CONV, and the greatest weed density level observed in LI. Seed yield was determined by the farming system; the greatest in CONV and significantly lower in LI (by $0.73 \mathrm{t} \mathrm{h}^{-1}$ ) and MI (by $0.18 \mathrm{t} \mathrm{ha}^{-1}$ ). Little difference was observed in seed yield between cultivars. The greatest production values for the Kalif and Regent cultivars (996€ and $949 € \mathrm{ha}^{-1}$, respectively) were recorded in CONV, although LI proved to be the most profitable (with the highest gross agricultural income and lowest total cost of production). LI farming systems, in conjunction with chemical weed control, should be investigated in future studies.
\end{abstract}

Keywords: lupin; yielding; weed infestation; cultivation intensification; production cost

\section{Introduction}

With an ever-increasing human population, the agricultural sector is confronted with a number of critical challenges, namely, how to produce sufficient volumes of food for this population, while at the same time preventing the pollution of natural ecosystems [1]. According to Fess et al. [2], high-input farming systems become less sustainable and practical as the global population increases, because of reduced requirement of resources.

Legume crops can be cultivated under both organic and sustainable farming systems [3]. Pulse crops, such as white lupin (Lupinus albus L.), yellow lupin (Lupinus luteus L.), and narrow-leaved 
lupin (Lupinus angustifolius L.) are native European plants, and could provide an excellent source of plant protein $[4,5]$. Legumes are also very important in plant production systems, as they fix atmospheric nitrogen $\left(\mathrm{N}_{2}\right)$, thereby increasing the soil concentration of a fundamentally important plant nutrient. In European conditions, the most widely cultivated grain legumes (e.g., lupin, faba bean, and field pea) accumulate an average of $130-153 \mathrm{~kg} \mathrm{~N} \mathrm{ha}^{-1}$ (from biological fixation) in their aboveground biomass [6]. Indeed, the potential range of $\mathrm{N}$ fixation in lupin is even wider, with values of $300 \mathrm{~kg} \mathrm{~N} \mathrm{ha}^{-1}$ reported in some studies [7]. Crews and Peoples [8] concluded that the supply of $\mathrm{N}$ from legumes (biological) may be a more sustainable source than synthetic (chemical) sources. Moreover, while some countries are very dependent on the latter for food production, many have the capability to substantially reduce synthetic $\mathrm{N}$ dependence through the adoption of less meat-intensive diets, and through the reduction of food waste [8]. While many national governments in Europe support the production of legume crops, economic impetus for legume cultivation is lacking, especially in areas where cereal and oilseed crops grow well [9]. However, legume cultivation could provide more plant protein, and also lead to increased biodiversity levels in crop rotations [10]. Modern, high-performance crop varieties are usually bred for high-input farming systems [2], although more environment-friendly cultivation methods have been sought $[11,12]$. In studies concerning white lupin, the highest income and the lowest cost of production for $1 \mathrm{t}$ of seeds and $1 \mathrm{~kg}$ protein were provided by LI, but this type of farming system poses a risk of weed infestation, and reduces seed and protein yields. That is why LI farming system should be supplemented with chemical crop protection against weeds. As such, the low-input technology, along with supplemented chemical weed control, may be considered for higher seed and protein yields of lupin [13].

The objective of this study was to assess the influence of three farming systems (LI, MI, and CONV) on (a) weed infestation, (b) seed and protein yield, and (c) the economic effects of cultivation of two narrow-leaved lupin cultivars.

\section{Materials and Methods}

\subsection{Site Description}

The study was part of a long-term field experiment carried out at the Gorzyń Research Station, Poland ( $\left.52^{\circ} 34^{\prime} \mathrm{N}, 15^{\circ} 54^{\prime} \mathrm{E}\right)$. The soil type, according to the World Reference Base, is an Albic Luvisol that overlies a gray-brown podzolic. Total $\mathrm{N}$ content in the soil was $527 \mathrm{mg} \mathrm{kg}^{-1}$ soil, plant available phosphorus (P) was $13.9 \mathrm{mg} \mathrm{kg}^{-1}$ soil, and potassium (K) was $10.9 \mathrm{mg} \mathrm{kg}^{-1}$ soil. Weather conditions during the study are expressed as the hydrothermal coefficient of water supply according to the Sielianinov index $(K)$ (Table 1).

Table 1. Sielianinov index $(K)$ during the narrow-leaved lupin growing season (2011-2015), recorded at the Agrometeorological Observatory in Gorzyń, Poland.

\begin{tabular}{ccccccc}
\hline Year (Y) & April & May & June & July & August & Sum of Rainfall (mm) \\
\hline 2011 & 0.25 & 0.58 & 0.89 & 3.18 & 0.48 & 287 \\
2012 & 0.80 & 0.84 & 2.26 & 2.27 & 1.90 & 412 \\
2013 & 0.53 & 1.63 & 2.10 & 0.87 & 0.49 & 278 \\
2014 & 1.99 & 2.50 & 0.97 & 1.18 & 1.74 & 390 \\
2015 & 1.30 & 0.43 & 1.02 & 1.22 & 0.17 & 184 \\
\hline
\end{tabular}

$K:<0.5=$ drought, $0.5-1.0=$ semi-drought, $1.0-1.5=$ border of optimal moisture, $>1.5=$ excessive moisture.

The following formula was applied:

$$
K=(M o \times 10) /\left(D_{t} \times \text { days }\right)
$$

where $K$ is the hydrothermal coefficient for an individual month during the growing season, Mo is total monthly precipitation, and $D_{t}$ is the mean daily temperature in a particular month. 
During the study, there were considerable differences in the weather conditions during the growing season (Table 1). On average, 2011 and 2015 were least favorable for growth, because of low hydrothermal coefficients $(K)$. However, it should be noted that the Sielianinov coefficient was at least 1.0 during the period of greatest demand for water by the plants, i.e., during florescence (June) and pod emergence (July), which means that the narrow-leaved lupin plants had a relatively good supply of water during their most critical development period.

\subsection{Experimental Design and Agronomic Management}

The field experiment was replicated at the same location every year over a 5 -year period (2011-2015). Four replicates of the two-factors were evaluated in a split-plot design. The main plot factor was the farming system: low-external input (LI), medium-input (MI), and high-input (conventional-CONV). The second plot factor was narrow-leaved lupin cultivar (indeterminate cv. Kalif and determinate cv. Regent). A detailed description of the farming systems employed in this study can be found in Table 2 . In MI and CONV systems, herbicides were used to target particular plant species: chlorothalonil was used once in 2011, and then three times in each growing season (2012-2015); alfa-cypermethrin was applied once per growing season.

Table 2. Characteristics of the farming systems evaluated in this study.

\begin{tabular}{|c|c|c|c|}
\hline \multirow{2}{*}{$\begin{array}{l}\text { Agronomic } \\
\text { Treatment }\end{array}$} & \multicolumn{3}{|c|}{ Farming System } \\
\hline & LI & MI & CONV \\
\hline $\begin{array}{c}\text { Seed } \\
\text { conditioning }\end{array}$ & $\begin{array}{l}\text { Bradyrhizobium } \\
\text { lupini }\end{array}$ & $\begin{array}{c}\text { carboxin, thiram } \\
\text { (350 mL per } 100 \mathrm{~kg} \text { of seeds) } \\
\text { Bradyrhizobium lupini }\end{array}$ & $\begin{array}{c}\text { carboxin, thiram }(350 \mathrm{~mL} \text { per } \\
100 \mathrm{~kg} \text { of seeds) } \\
\text { Bradyrhizobium lupini }\end{array}$ \\
\hline Weed control & mechanical & $\begin{array}{c}\text { Mechanical } \\
\text { linuron }\left(1.01 \mathrm{~h}^{-1}\right) \\
\text { (direct after sowing) }\end{array}$ & $\begin{array}{l}\text { linuron }\left(1.0 \mathrm{~L} \mathrm{ha}^{-1}\right)+\text { clomazone } \\
\left(0.2 \mathrm{~L} \mathrm{ha}^{-1}\right) \\
\text { (direct after sowing) } \\
\text { metamitron }\left(1.5 \mathrm{~L} \mathrm{ha}^{-1}\right) \\
\text { (after emergence) }\end{array}$ \\
\hline $\begin{array}{l}\text { Soil fertilization } \\
\qquad\left(\mathrm{kg} \mathrm{ha}^{-1}\right)\end{array}$ & - & N-15; P-21.8; K-58.1 & N-30; P-30.5; K-83 \\
\hline $\begin{array}{l}\text { Foliar application } \\
\text { of fertilizers }\end{array}$ & - & - & $\begin{array}{l}\text { multiple micro- and } \\
\text { macroelements }\end{array}$ \\
\hline Disease control & - & $\begin{array}{l}\text { chlorothalonil }\left(2.01 \mathrm{ha}^{-1}\right) \\
\text { (tatrachloroizoftalonitryl) } \\
\text { for Anthracnose }\end{array}$ & $\begin{array}{l}\text { chlorothalonil }\left(2.0 \mathrm{~L} \mathrm{ha}^{-1}\right) \\
\text { (tatrachloroizoftalonitryl) } \\
\text { for Anthracnose }\end{array}$ \\
\hline Insects control & - & - & $\begin{array}{l}\text { alfa-cypermethrin }\left(0.1 \mathrm{~L} \mathrm{ha}^{-1}\right) \\
\text { (after emergence) } \\
\text { for Sitona spp. }\end{array}$ \\
\hline $\begin{array}{c}\text { Desiccation } \\
\text { before harvest }\end{array}$ & - & - & $\begin{array}{c}\text { diquat }\left(2.5 \mathrm{~L} \mathrm{ha}^{-1}\right) \\
\text { (dibromide formula) }\end{array}$ \\
\hline
\end{tabular}

Farming system: $\mathrm{LI}=$ low external input; $\mathrm{MI}=$ medium input; $\mathrm{CONV}$ = conventional.

The area of each single experimental plot was $20 \mathrm{~m}^{2}$. Lupin was cultivated in crop rotation: legumes, winter rape, and cereals. The forecrop was winter wheat (Triticum aestivum), which was cultivated in a conventional tillage system, where $\mathrm{P}$ and $\mathrm{K}$ fertilizers were applied in autumn $\left(80 \mathrm{~kg} \mathrm{P} \mathrm{ha}^{-1}, 100 \mathrm{~kg} \mathrm{~K} \mathrm{ha}{ }^{-1}\right)$. Winter wheat $\mathrm{N}$ fertilization rates $\left(\mathrm{NH}_{4} \mathrm{NO}_{3} ; \mathrm{N} 34 \%\right)$ were as follows: $60 \mathrm{~kg} \mathrm{~N} \mathrm{ha}^{-1}$ (early spring, before the start of crop growth); $120 \mathrm{~kg} \mathrm{~N} \mathrm{ha}^{-1}$ (the second rate during straw shooting phase); and $180 \mathrm{~kg} \mathrm{~N} \mathrm{ha}^{-1}$ (the third rate during earing). Each year, the soil was ploughed after harvest of the forecrop (winter wheat) in autumn, and was harrowed in spring before lupin was sown. Recommended sowing rates were as follows: 100 seeds $\mathrm{m}^{-2}$ for indeterminate Kalif, and 115 seeds $\mathrm{m}^{-2}$ for determinate Regent. Seeds were sown at a depth of $4 \mathrm{~cm}$ in rows spaced at $18 \mathrm{~cm}$ intervals in early April. In all systems, plots were drilled with a double disk drill (Great Plains, Solid Stand 100 equipped with a fluted coulter for residue cutting, a double disk for seed placement, 
and a press wheel ( $3 \mathrm{~m}$ wide). Weight of the tractor was $2885 \mathrm{~kg}$ ). Each year, lupin was harvested in August with a 1.5-m-wide Wintersteiger plot combine harvester.

\subsection{Data Collection}

During each growing season, weed infestation was assessed on each plot two weeks before harvest. Weeds collected from the site were dried in a laboratory at $80^{\circ} \mathrm{C}$ for $48 \mathrm{~h}$. Weed infestation was expressed as the number and dry mass of weeds per unit area $\left(\mathrm{m}^{2}\right)$ and as the percentage share of specific species in the total number of weeds in each farming system.

For narrow-leaved lupin, the following traits were assessed: plant density $/ \mathrm{m}^{2}$ before harvest, the biometric traits of 10 randomly selected plants before harvest (the number of pods/plant, number of seeds/plant, and number of seeds/pod), and the mass of 1000 seeds (seeds collected from the harvested seed mass; $2 \times 500$ seeds were counted and weighed). Seed yield/ha was calculated at the $15 \%$ moisture level. Analyses of seed protein content were carried out in the laboratory, according to Kjeldahl ( $\mathrm{N}$ values were multiplied by 6.25) [14]. Seed protein content was expressed on a dry weight basis $\left(\mathrm{g} \mathrm{kg}^{-1}\right)$, and was recalculated as protein yield $\left(\mathrm{kg} \mathrm{ha}^{-1}\right)$.

Economic analysis of each farming system was evaluated with data from the experimental plots, i.e., machinery operations, inputs, and average yields. Direct costs for all farming systems included seeds, cultivation, seed conditioning, mechanical weed control, and harvest. For the MI and CONV systems, additional direct costs accrued from disease and insect control, and desiccation before harvest (only in CONV). Overall costs included the cost of seeds, fertilizers, chemical crop protection, machinery operations, labor, and services. All calculations were based on 2015 prices. The cost of seeds, fertilizers, and plant protection (herbicides, fungicides, and insecticides) were estimated from agricultural dealers and from national-level market prices [15]. Crop subsidy data were taken from the Agency for Restructuring and Modernization of Agriculture [16]. Subsidies included single area payment (107.59€), additional payment for legumes (241.18€), and direct payments for seeds (30.83€). All prices and costs were recalculated in euro $(€)$ according to the monthly average exchange rate in September 2015 [17].

\subsection{Statistical Analysis}

The impact of farming system on lupin cultivar traits was examined with two-way analysis of variance (ANOVA) using SAS PROC GLM (SAS Institute Inc. 1996). Least significant difference was verified with Tukey's multiple range test at $p<0.01$ and $p<0.05$ significance levels. Relationships between parameters were determined with the Pearson correlation coefficient. Interpretation of Pearson's linear correlation coefficient was conducted according to Stanisz [18]. Correlations between traits in each farming system were determined using SAS PROC CORR.

\section{Results}

Weed community composition was affected by the farming system (Table 3). A total of 12 weed species were identified: 11 in LI, 8 in MI, and 8 in CONV. POLCO (Polygonum convolvules (L.) A. Löve) and CHEAL (Chenopodium album L.) were the most frequently observed species across all farming systems, at $43-49 \%$ and $27-32 \%$, respectively. Less frequently observed species were LYCAR (Anchusa arvensis L.), CAPBP (Capsella bursa-pastoris (L.) Medik.), CONAR (Convolvulus arvensis L.), GALAP (Galium aparine L.), and LAMAM (Lamium amplexicanle L.), and accounted for $<1 \%$ in all farming systems. Lowest weed density and biomass values were recorded in CONV, and the greatest values were recorded in LI (Table 4). Weed dry weight was significantly lower in MI and CONV (approximately $18 \%$ and $33 \%$, respectively), compared to LI. The number of weeds $/ \mathrm{m}^{2}$ was $54 \%$ greater in LI compared to CONV, but there was no difference between MI and CONV. Cultivar factor did not influence the number of weeds, although weed dry mass was significantly lower (by 18\%) under Regent cultivation than Kalif. 
Table 3. Effect of farming system on botanical composition of weeds in the study plots (share, \%).

\begin{tabular}{ccccc}
\hline & & \multicolumn{3}{c}{ Farming System } \\
\cline { 3 - 5 } Latin Binomial & Bayer Code & LI & MI & CONV \\
\hline Agropyron repens (L.) Beauv. & AGRRE & 4 & 2 & 0 \\
Anchusa arvensis L. & LYCAR & 1 & 0 & 1 \\
Capsella bursa-pastoris (L.) Medik. & CAPBP & 1 & 0 & 0 \\
Chenopodium album L. & CHEAL & 27 & 31 & 32 \\
Convolvulus arvensis L. & CONAR & 0 & 0 & 1 \\
Echinochola crus-galli (L.) Beauv. & ECHCG & 4 & 8 & 11 \\
Galinsoga parviflora Cav. & GASPA & 2 & 3 & 0 \\
Galium aparine L. & GALAP & 1 & 1 & 0 \\
Lamium amplexicanle L. & LAMAM & 1 & 0 & 1 \\
Polygonum convolvules (L.) A. Löve & POLCO & 49 & 46 & 43 \\
Polygonum lapathifolium L. & POLLA & 5 & 1 & 6 \\
Viola arvensis Murr. & VIOAR & 5 & 8 & 5 \\
\hline LSD Value & & $4.72 * *$ & \\
\hline Number of species & No. & 11 & 8 & 8
\end{tabular}

Significance: ${ }^{* *} p<0.01$. Farming system: LI = low external input; $\mathrm{MI}=$ medium input; $\mathrm{CONV}=$ conventional.

Table 4. Effect of farming system and cultivar type on level of weed infestation, yield, and seed protein content.

\begin{tabular}{|c|c|c|c|c|}
\hline \multirow{2}{*}{ Specification } & \multicolumn{3}{|c|}{ Farming System } & \multirow{2}{*}{ LSD Value } \\
\hline & LI & MI & CONV & \\
\hline Dry weight of weeds (g) & 243.9 & 199.0 & 162.7 & $24.02 * *$ \\
\hline Number of weeds & 97.7 & 80.8 & 63.5 & $17.83^{* *}$ \\
\hline Plant density (no. $\mathrm{m}^{2}$ ) & 72.9 & 77.7 & 75.2 & NS \\
\hline Number of pods per plant & 6.0 & 7.3 & 7.7 & $1.09^{* *}$ \\
\hline Number of seeds per plant & 23.2 & 25.4 & 27.1 & NS \\
\hline Number of seeds per plant pod & 3.9 & 3.5 & 3.5 & $0.24^{* *}$ \\
\hline Mass of 1000 seeds $(\mathrm{g})$ & 137.1 & 136.6 & 137.0 & NS \\
\hline \multirow[t]{3}{*}{ Protein content in seeds $\left(\mathrm{g} \mathrm{kg}^{-1}\right)$} & 307 & 304 & 317 & NS \\
\hline & \multicolumn{3}{|c|}{ Cultivar } & \\
\hline & Kalif & & Regent & \\
\hline Dry weight of weeds (g) & 221.5 & & 182.2 & $37.82 *$ \\
\hline Number of weeds & 85.3 & & 76.9 & NS \\
\hline Plant density (no. $\mathrm{m}^{2}$ ) & 68.9 & & 81.6 & $3.38^{* *}$ \\
\hline Number of pods per plant & 7.6 & & 6.4 & $0.71^{* *}$ \\
\hline Number of seeds per plant & 27.7 & & 22.8 & $3.08 * *$ \\
\hline Number of seeds per plant pod & 3.6 & & 3.6 & NS \\
\hline Mass of 1000 seeds $(\mathrm{g})$ & 141.5 & & 132.2 & $3.58 * *$ \\
\hline Protein content in seeds $\left(\mathrm{g} \mathrm{kg}^{-1}\right)$ & 313 & & 306 & NS \\
\hline
\end{tabular}

NS: non-significant; ${ }^{*} p<0.05$ and ${ }^{* *} p<0.01$. System: $\mathrm{LI}=$ low external input; $\mathrm{MI}=$ medium input; $\mathrm{CONV}=$ conventional.

Farming system intensity substantially affected the numbers of pods and seeds/plant pod (Table 4). However, this factor did not have an impact on plant density, seeds/plant, or the 1000 seed mass. A significantly greater number of pods/plant were observed in the MI and CONV systems, although the number of seeds/plant pod were significantly lower than in LI. Cultivar type was found to modify yield components; a significantly greater plant density was observed in the Regent cultivar, and a significantly lower number of pods and seeds/plant and 1000 seed mass compared to Kalif. There was no significant difference in seed protein content between experimental factors.

No significant interactions were observed between the experimental factors and protein and seed yield (Table 5). The greatest protein yield was observed in CONV, and was significantly lower in LI 
and MI (by 31.3\% and 11\%, respectively). Although no significant differences were observed in seed yield between cultivars, the protein yield in Regent was substantially lower (by $54 \mathrm{~kg} \mathrm{ha}^{-1}$ ). Seed yield was strongly affected by farming system, and the greatest yield was recorded in CONV, and was significantly lower in LI (by $0.73 \mathrm{tha}^{-1}$ ) and MI (by $0.18 \mathrm{tha}^{-1}$ ).

Table 5. Narrow-leaved lupin protein yield $\left(\mathrm{kg} \mathrm{ha}^{-1}\right)$ and seed yield $\left(\mathrm{t} \mathrm{ha}^{-1}\right)$.

\begin{tabular}{|c|c|c|c|c|}
\hline \multirow{3}{*}{ Cultivar (C) } & \multicolumn{3}{|c|}{ Farming System (FS) } & \multirow{3}{*}{ Mean } \\
\hline & LI & MI & CONV & \\
\hline & \multicolumn{3}{|c|}{ Protein Yield } & \\
\hline Kalif & 488 & 641 & 714 & 614 \\
\hline Regent & 452 & 575 & 654 & 560 \\
\hline Mean & 470 & 608 & 684 & \\
\hline \multirow[t]{2}{*}{ LSD value } & \multicolumn{3}{|c|}{ FS $-33.3^{* *} ; \mathrm{C}-46.4^{*} ; \mathrm{FS} \times \mathrm{C}-\mathrm{NS}$} & \\
\hline & \multicolumn{3}{|c|}{ Seed Yield } & \\
\hline Kalif & 1.85 & 2.45 & 2.26 & 2.31 \\
\hline Regent & 1.75 & 2.25 & 2.44 & 2.15 \\
\hline Mean & 1.80 & 2.35 & 2.53 & \\
\hline LSD value & \multicolumn{3}{|c|}{$\mathrm{FS}-0.13^{* *} ; \mathrm{C}-\mathrm{NS} ; \mathrm{FS} \times \mathrm{C}-\mathrm{NS}$} & \\
\hline
\end{tabular}

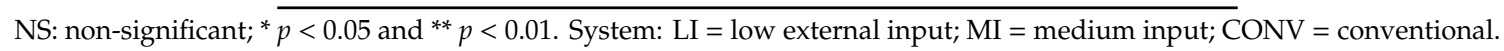

In each farming system, functional relationships were observed between the number of pods/plant and the number of seeds/plant, and seed yield and protein yield (Figure 1). However, correlations between the number of seeds/plant pod and seed yield and the protein yield in LI were also practically functional relationships. Negative relationships were observed between the number of weeds and seed yield and protein yield; strong in LI, poor in MI, and practically functional in CONV.

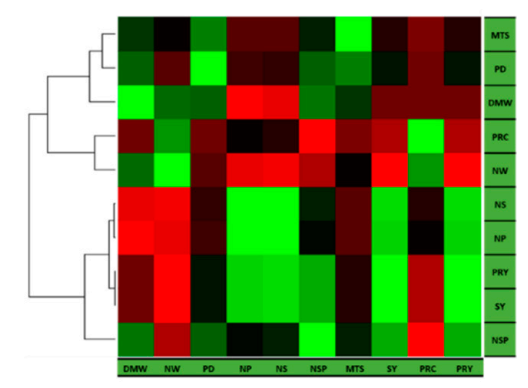

CONV

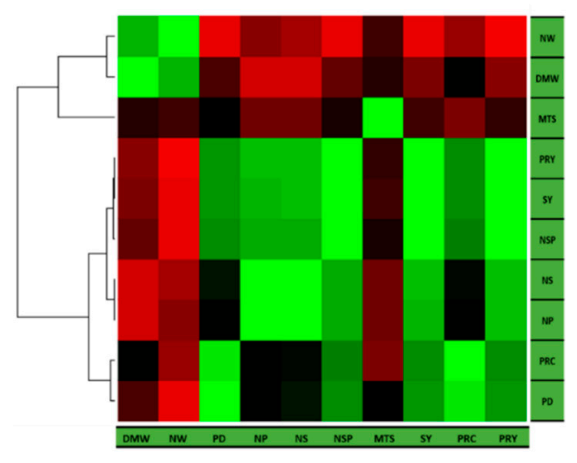

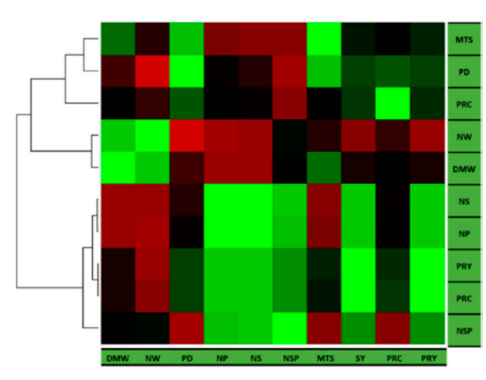

MI

Interpretation of Pearson's linear correlation coefficient

$0 \leq r<0.2$ - practically no relation between characters;

$\square .2 \leq r<0.5$ - poor relation between characters;

$\square 0.5 \leq r<0.75$ - medium relation;

$\square 0.75 \leq r<0.95$ - strong relation;

$0.95 \leq r<1.00$ - practically functional relation.

LI

Figure 1. Correlation coefficients between analyzed parameters. System (FS): LI = low input; $\mathrm{MI}=$ medium input; $\mathrm{CONV}=$ conventional. Parameters compared: DMW = dry mass of weeds; $\mathrm{NW}=$ number of weeds; $\mathrm{PD}=$ plant density; $\mathrm{NP}=$ number of pods/plant; NS = number of seeds/plant; $\mathrm{NSP}=$ number of seeds/plant pod; MTS = mass of 1000 seeds; $S Y=$ seed yield; $P R C=$ protein content; PRY = protein yield. 
In both cultivars, the highest production values were recorded in CONV, which also had the greatest cost of seeds and protein production, and the lowest gross agricultural income (Table 6). The LI system proved to be the most profitable (i.e., gross agricultural income) for both Kalif and Regent cultivation, and the total cost of production was also lowest.

Table 6. Economic analysis of the profitability of narrow-leaved lupin cultivation under different farming systems (all values expressed in euro).

\begin{tabular}{|c|c|c|c|c|c|c|}
\hline \multirow{3}{*}{ Specification } & \multicolumn{4}{|c|}{ Kalif } & \multicolumn{2}{|c|}{ Regent } \\
\hline & \multicolumn{6}{|c|}{ Farming System } \\
\hline & LI & MI & CONV & LI & MI & CONV \\
\hline Production value * $\mathrm{ha}^{-1}$ & 830.17 & 972.45 & 996.16 & 806.45 & 925.00 & 948.74 \\
\hline Total cost ha ${ }^{-1}$ & 353.87 & 546.40 & 886.16 & 387.98 & 580.50 & 920.28 \\
\hline Gross agricultural income ha ${ }^{-1}$ & 476.30 & 426.06 & 110.00 & 418.47 & 344.50 & 28.46 \\
\hline Cost of $1 \mathrm{t}$ seed production ** & 186.25 & 218.56 & 340.83 & 215.54 & 252.39 & 383.45 \\
\hline Cost of $1 \mathrm{~kg}$ protein production $* * *$ & 0.73 & 0.85 & 1.24 & 0.86 & 1.01 & 1.41 \\
\hline
\end{tabular}

System: LI = low external input; $\mathrm{MI}=$ medium input; $\mathrm{CONV}=$ conventional. * (average yield $\mathrm{ha}^{-1} \times €$ 237. 14, price of $1 \mathrm{t}$ seeds $)+€ 379.60$ EU subsidies, ${ }^{* *}$ Total cost/ average yield $\mathrm{ha}^{-1},{ }^{* * *}$ Total cost/ average protein yield $\mathrm{ha}^{-1}$.

\section{Discussion}

Our study suggests that weed community assembly was affected by the farming system. A total of 12 weed species were identified, and the lowest weed density $/ \mathrm{m}^{2}$ and biomass $/ \mathrm{m}^{2}$ values were observed with the CONV system, and the greatest were observed in LI. The number of weeds $/ \mathrm{m}^{2}$ was $54 \%$ greater in $\mathrm{LI}$ compared to CONV, and there was no difference between MI and CONV. The greater weed infestation is due to the absence of herbicide use, and the mechanical treatment employed in the LI system was insufficient to improve lupin competitiveness. Our results are in agreement with Poudel et al. [19], who also found that low-input systems generally have greater aboveground weed biomass and more weed competition in comparison to conventional systems. Others researchers who have analyzed the influence of farming systems on the cultivation of lupin species (yellow, narrow-leaved, and white lupin) have reported significantly greater weed infestation levels in plots that received only mechanical treatment [20]. In the study by Borowska et al. [20], the application of herbicides in medium-input and high-input systems significantly reduced both the level of weed infestation and the weed dry weight of all lupin species. However, additional herbicide application after sowing and post-emergence in the high-input system did not significantly reduce weed dry weight. Chemical weed control should carefully consider the sensitivity of the crop to the herbicide, followed by observation of the application technology, as well as important aspects, such as compound mixture, ambient environmental conditions, and the use of adjuvants [21].

Weed infestation intensity in individual farming systems can be modified not only by the type of treatment applied, but also by the number of lupin plants per area unit. In our study, significantly lower weed dry mass was observed with Regent cultivation, compared to Kalif. We suggest that the determinate cultivar Regent is more competitive than the indeterminate cultivar Kalif, because it exhibited a significantly greater density of plants per area unit, due to higher recommended sowing rates. Farming system did not influence plant density in our study, in contrast to Suliman [22], who showed that conventional tillage and mechanical weed control significantly increased legume plant density.

Our results show that the weed infestation can influence narrow-leaved lupin productivity. Pearson's linear correlation indicated a negative relationship between number of weeds and seed and protein yields, which was strong in LI, poor in MI, and practically functional in CONV. This means that when the number of weeds increase, protein and seed yields decrease, depending on the farming system employed. Weeds in lupin crops have become increasingly difficult to control [23]. In our study, the greatest narrow-leaved lupin protein and seed yields were found in CONV (compared to 
LI and MI), although the yield in this system primarily depended on the number of weeds present. Borowska et al. [20] found that seed yield in white and narrow-leaved lupin was significantly greater in the high-input system, while yellow lupin yield was greatest in the high- and medium-input systems. A significant increase in seed yield, along with an increasing intensity of the cultivation in the case of traditional and self-completing cultivars of white and yellow lupin, as well as self-completing cultivars of narrow-leaved lupin, resulted mainly from the development of a higher number of pods. Szymańska et al. [24] also studied the influence of farming system on the development and yield of yellow lupin, and observed that seed yield was $13.1 \%$ and $22.0 \%$ greater in the MI and CONV systems, respectively, than in LI. Their research also highlighted differences in cultivar yield; the indeterminate cultivar Mister produced more seeds than the determinate cultivar Perkoz $\left(1.95 \mathrm{t} \mathrm{ha}^{-1} \mathrm{vs} .1 .81 \mathrm{t} \mathrm{ha}^{-1}\right)$. In our experiment, there was no significant difference in seed yield between lupin cultivars. We observed significantly lower pod numbers, seeds/plant, and the 1000 seed mass in Regent, compared to Kalif. Determinate lupin cultivars have been reported to exhibit a reduced number of branches to improve the maturation of the plants.

In our study, farming system was also found to modify the yield components. We found a significantly greater number of pods/plant in MI and CONV (compared to LI), but substantially lower numbers of seeds/plant pod. Borowska et al. [20] observed a non-significant difference in the number of pods/plant between medium- and high-input systems, as well as between low- and medium-input systems for all lupin species in their study. Szymańska [24], studying yellow lupin yield components, found that differences in farming system intensity and cultivar type significantly influenced the number of pods and seeds/plant. However, these factors had no influence on the number of seeds/pod or the 1000 seed weight.

Lupin is valued mainly for its high protein content. In our experiment, protein content in seeds ranged from 304 to $317 \mathrm{~g} \mathrm{~kg}^{-1}$. Protein yield in Regent was lower (by $54 \mathrm{~kg} \mathrm{ha}^{-1}$ ) compared to Kalif, and the greatest protein yield was found in CONV and was significantly lower in LI and MI. A practically functional relationship was observed between protein yield and seed yield in each farming system. This is because of method of calculation of protein yield. In our experiment, the cost of protein and seed production was greatest in CONV, but gross agricultural income was also lowest in this system. According to Czerwińska-Kayzer and Florek [25], gross agricultural income is a basic economic category that is indicative of the profitability of agricultural production. In our study, the LI system (greatest gross agricultural income and lowest total cost of production) proved to be the most profitable for both cultivars. According to Szymańska et al. [24], increased expenditure in CONV farming systems can lead to a decrease in gross agricultural income; in our experiment, the cost of production of 1 tonne of seeds (for on-farm feed production) was lowest in the LI system. Although production was greatest in CONV, the greater cultivation intensity (in yellow lupin) observed in Szymańska et al. [24] was not economically justified (compared to cultivation of narrow-leaved lupin in our experiment). Moreover, work by Panasiewicz et al. [26] showed that the increase in narrow-leaved lupin seed yield produced by a more intensive tillage option (conventional tillage) compensated for the increase in overall costs.

Aside from economic performance, high-input farming systems may lead to increased environmental problems, as a consequence of the fertilizers and pesticides applied during the course of cropping operations. As legumes support biological $\mathrm{N}_{2}$ fixation, they offer a more environmentally robust and sustainable $\mathrm{N}$ source for cropping systems [8]. At zero fertilization levels, weeds (due to extremely strong competition for soil $\mathrm{N}$ ) might force lupin plants to depend more on $\mathrm{N}$ fixation, thereby making the $\mathrm{N}$ fixation process more efficient.

\section{Conclusions}

Our economic analysis indicates that the greatest income and the lowest cost of production for both narrow-leaved lupin cultivars were provided by the LI farming system, although this type of farming system does carry a risk of elevated weed infestation levels and reduced seed and protein 
yields. Therefore, LI farming systems, used in conjunction with chemical weed control, should be investigated in future studies.

Author Contributions: A.F. and K.P. conceived and designed the experiments; A.F., K.P., G.S., K.R., and H.S. performed the field experiments and analyzed the data; A.F. and K.R. performed statistical analysis; K.P. and G.S. described the materials and methods; H.S., A.P., and A.K. prepared the references; A.F. wrote the manuscript; A.F., K.P., G.S., K.R., H.S., A.P., and A.K. revised the manuscript. All authors have read and agreed to the published version of the manuscript.

Funding: This research was funded by Polish Ministry of Agriculture and Rural Development (Project number HOR 3.3/2011-2015)

Acknowledgments: This study was funded by a grant from the Polish Ministry of Agriculture and Rural Development, Project: Improving domestic sources of plant protein, their production, trading and use in animal feed, project No. HOR 3.3/2011-2015.

Conflicts of Interest: The authors declare no conflict of interest.

\section{References}

1. Bhardwaj, H.L.; Hamama, A.A.; Van Santen, E. White Lupin Performance and Nutritional Value as Affected by Planting Date and Row Spacing. Agron. J. 2004, 96, 580-583. [CrossRef]

2. Fess, T.; Kotcon, J.B.; Benedito, V.A. Crop Breeding for Low Input Agriculture: A Sustainable Response to Feed a Growing World Population. Sustainability 2011, 3, 1742. [CrossRef]

3. Księżak, J.; Staniak, M.; Bojarszczuk, J. The regional differentiation of legumes cropping area in Poland between 2001 and 2007. Pol. J. Agron. 2009, 1, 25-31.

4. Sujak, A.; Kotlarz, A.; Strobel, W. Compositional and nutritional evaluation of several lupin seeds. Food Chem. 2006, 98, 711-719. [CrossRef]

5. Annicchiarico, P.; Harzic, N.; Carroni, A.M. Adaptation, diversity, and exploitation of global white lupin (Lupinus albus L.) landrace genetic resources. Field Crop. Res. 2010, 119, 114-124. [CrossRef]

6. Peoples, M.B.; Brockwell, J.; Herridge, D.F.; Rochester, I.J.; Alves, B.J.R.; Urquiaga, S.; Boddey, R.M.; Dakora, F.D.; Bhattarai, S.; Maskey, S.L.; et al. The contributions of nitrogen-fixing crop legumes to the productivity of agricultural systems. Symbiosis 2009, 48, 1-17. [CrossRef]

7. Sulas, L.; Canu, S.; Ledda, L.; Carroni, A.M.; Salis, M. Yield and nitrogen fixation potential from white lupine grown in rainfed Mediterranean environments. Sci. Agricola 2016, 73, 338-346. [CrossRef]

8. Crews, T.E.; Peoples, M. Legume versus fertilizer sources of nitrogen: Ecological tradeoffs and human needs. Agric. Ecosyst. Environ. 2004, 102, 279-297. [CrossRef]

9. Murphy-Bokern, D.; Watson, C. Legume-supported cropping systems for Europe. In Looking Forward 2016. Available online: http://www.legumefutures.de/images/Legume_Futures_Looking_Forward.pdf (accessed on 18 August 2020).

10. Preissel, S.; Reckling, M.; Schläfke, N.; Zander, P. Magnitude and farm-economic value of grain legume pre-crop benefits in Europe: A review. Field Crop. Res. 2015, 175, 64-79. [CrossRef]

11. Pelzer, E.; Bazot, M.; Makowski, D.; Corre-Hellou, G.; Naudin, C.; Al Rifaï, M.; Baranger, E.; Bedoussac, L.; Biarnès, V.; Boucheny, P.; et al. Pea-wheat intercrops in low-input conditions combine high economic performances and low environmental impacts. Eur. J. Agron. 2012, 40, 39-53. [CrossRef]

12. Jaśkiewicz, B. The impact of production technology on yields of spring triticale under varied percentages of cereals to total cropped area. Fragm. Agron. 2017, 34, 7-17. (In Polish)

13. Faligowska, A.; Panasiewicz, K.; Szymańska, G.; Szukala, J.; Koziara, W.; Pszczółkowska, A. Productivity of white lupin (Lupinus albus L.) as an effect of diversified farming systems. Legum. Res. Int. J. 2017, 40, 872-877. [CrossRef]

14. AOAC. Official Methods of Analysis; Association of Official Analytical Chemists: Washington, DC, USA, 1975.

15. Ceny Rolnicze. Available online: http://www.cenyrolnicze.pl (accessed on 20 August 2020).

16. Agency for Restructuring and Modernization of Agriculture. Available online: https://www.arimr.gov.pl/ (accessed on 20 August 2020).

17. Central Bank of the Republic of Poland. Available online: http://www.nbp.pl/homen.aspx?f=/kursy/kursyen. htm (accessed on 20 August 2020).

18. Stanisz, A. Approachable Statistics Course; StatSoft: Krakow, Poland, 1998; p. 362. (In Polish) 
19. Poudel, D.; Horwath, W.; Lanini, W.; Temple, S.; Van Bruggen, A. Comparison of soil N availability and leaching potential, crop yields and weeds in organic, low-input and conventional farming systems in northern California. Agric. Ecosyst. Environ. 2002, 90, 125-137. [CrossRef]

20. Borowska, M.; Prusinski, J.; Kaszkowiak, E. Production results of intensification of cultivation technologies in three lupin (Lupinus L.) species. Plant Soil Environ. 2016, 61, 426-431. [CrossRef]

21. Dos Reis, A.R.; Vivi, R. Weed Competition in the Soybean Crop Management in Brazil. In Soybean-Applications and Technology; IntechOpen: London, UK, 2011; pp. 185-210. Available online: https://www.intechopen.com/ books/soybean-applications-and-technology/weed-competition-in-the-soybean-crop-management-in-brazil (accessed on 20 August 2020).

22. Suliman, A.A.M. Contribution of weed control and tillage systems on soil moisture content, growth and forage quality of (Clitoria\&Siratro) mixture under-rainfed conditions at Zalingei-Western Darfur state-Sudan. J. Sci. Technol. 2008, 3, 80-90.

23. Anonymous. The Biology of Lupinus L. (Lupin or Lupine); Australian Government; Version 1: April 2013; Department of Health and Ageing, Office of the Gene Technology Regulator: Canberra, Australia, 2013; p. 64.

24. Szymańska, G.; Faligowska, A.; Panasiewicz, K.; Szukała, J.; Koziara, W. The productivity of two yellow lupine (Lupinus luteus L.) cultivars as an effect of different farming systems. Plant Soil Environ. 2017, 63, 552-557. [CrossRef]

25. Czerwińska-Kayzer, D.; Florek, J. Profitability of selected legumes. Fragm. Agronomy 2012, 29, 36-44. (In Polish)

26. Panasiewicz, K.; Faligowska, A.; Szymańska, G.; Szukała, J.; Ratajczak, K.; Sulewska, H. The Effect of Various Tillage Systems on Productivity of Narrow-Leaved Lupin-Winter Wheat-Winter Triticale-Winter Barley Rotation. Agronomy 2020, 10, 304. [CrossRef]

(C) 2020 by the authors. Licensee MDPI, Basel, Switzerland. This article is an open access article distributed under the terms and conditions of the Creative Commons Attribution (CC BY) license (http://creativecommons.org/licenses/by/4.0/). 